\title{
Analysis of Students' Conceptual and Procedural Knowledge in Solving Mathematics
}

\author{
Dita Felia 1 , Eni Defitriani ${ }^{2}$ \\ 1 Universitas Batanghari, INDONESIA \\ 2 Universitas Batanghari, INDONESIA
}

ARTICLE'S

INFORMATION

\section{Article history:}

Received: Nov-27-2021

Reviewed: Dec-01-2021

Accepted: Dec-27-2021

$\begin{array}{lr}\text { Keywords: } & \text { Conceptual } \\ \text { Knowledge, } & \text { Mathematics } \\ \text { Problem, } & \text { Procedural } \\ \text { Knowledge } & \end{array}$

\section{Corresponding address:}

Eni Defitriani,

\begin{abstract}
This study aims to describe the analysis of students' conceptual and procedural knowledge in solving mathematical problems. The research method used is descriptive qualitative. The subjects in this study were three grade VIII students in a junior high school in Jambi City, who had high, medium, and low math skills. The sampling technique was carried out by purposive sampling. The instrument in this study was the researcher himself and was assisted by other instruments, namely a conceptual-procedural knowledge test and interview guidelines. The results showed that high students had high conceptual and procedural abilities (meets all conceptual and procedural knowledge in solving problems), moderate students had moderate conceptual and procedural abilities (only met two indicators of conceptual knowledge and two indicators of procedural knowledge in solving problems). ), low students have low conceptual and procedural abilities (only fulfill one indicator of conceptual knowledge and do not meet any indicator of procedural knowledge in solving problems).
\end{abstract}

E-mail: eni.defitriani@unbari.ac.id

\section{INTRODUCTION}

Graduate Competency Standards that one of the competencies possessed by secondary education graduates is competence in the knowledge dimension, which includes factual, conceptual, procedural, and metacognitive knowledge. Conceptual and procedural knowledge is basic in the mathematics learning process [1]. Conceptual and procedural knowledge is needed in learning abstract study objects and symbols in mathematics.

Conceptual knowledge is defined as knowledge of mathematical concepts, concept definitions, principles, and relationships [2]; [3]; [4]. It includes not only what is known (knowledge of concepts) but also how it can be known (e.g., in and with rich connections)[2]. Conceptual knowledge can be measured by students' ability to identify related facts, recognize examples and non-examples, interpret signs, symbols, and terms, manipulate related ideas, and perfect the relationship between concepts and principles [3]. Indicators of conceptual knowledge are (1) restate the concepts that have been learned; (2) classify objects based on mathematical concepts; (3) apply the concept algorithmically; (4) give examples or counterexamples of the concepts being studied; (5) resenting concepts in various representations; and (6) relate various mathematical concepts internally or externally [6].

Procedural knowledge is defined as knowledge of procedures, formulas, and solution steps [4]; [2]; [3]; [5]. Procedural knowledge can be measured from students' knowledge of procedures in general, communicating algorithmic processes into problem situations, modifying procedures flexibly, precisely, and efficiently to address factors in problem-solving [6]. Indicators of procedural knowledge 
are (1) knowledge of procedures in general; (2) knowledge of when and how to use procedures properly; and (3) knowledge in performing procedures as well as being flexible, precise, and efficient.

The relationship between conceptual and procedural knowledge is two-way and iterative [4];[2]. Procedural tasks require knowledge of procedures and solution steps, while conceptual tasks require understanding concepts, rules, and relationships between concepts [4]. However, it is impossible to construct conceptual tasks requiring procedures and vice versa [4].

Knowledge of students' conceptual and procedural understanding based on ability level is important as a teacher. This is in line with the opinion [6] that the level of understanding of students' mathematical concepts is related to the level of mathematical ability. Teachers can use conceptual and procedural knowledge information as a reference in planning the learning process. Teachers must teach conceptual and procedural in one unit. If the teacher only teaches procedural skills without conceptual knowledge, students will easily forget the material being taught. Conversely, if the teacher only teaches concepts without procedural skills, students will have difficulty understanding, strengthening, and developing the concepts learned [6]. Thus, it is clear that conceptual and procedural skills are indispensable in solving mathematical problems [7]

According to Polya [8], there are four stages of solving mathematical problems: understanding the problem, devising a plan, carrying out the plan, and looking back. In the understanding the problem step or understanding the problem, students must understand the existing problem by determining and looking for what is known and what is asked in the problem. In devising a plan step or compiling a settlement plan, students must draw up a plan for solving the existing problem based on what has been known and ask about the problem in accordance with the first step. In the step of carrying out the plan or solving problems according to the plan, students must solve existing problems according to the plans made in the second step. In looking back a step or re-examining the results that have been obtained, students must be able to re-examine the results that have been obtained, whether the answer is correct and in accordance with what was asked in the problem or not.

Several studies on conceptual and procedural knowledge have been carried out by [9], [10]; [11]; [12]; [13], but no one has researched conceptual and procedural knowledge on Pythagorean materialbased on students' ability levels.

\section{METHODS}

The type of this research is descriptive qualitative research. This study describes students' conceptual and procedural knowledge in solving mathematical problems. The subjects in this study were three grade VIII students who had high, medium, and low abilities. Subjects were selected by purposive sampling technique. The considerations in selecting the subject are: students who have high, medium, and low abilities (based on the results of the Pythagorean chapter test) and communicative students (based on the opinion of the subject teacher).

The data in this study are data about students' conceptual and procedural knowledge in solving Pythagorean problems. Data collection techniques were carried out by using test and interview techniques. The instruments used are tests and interview guides. The test given is a Pythagorean material description test which consists of three questions. The interview guide explored the students' conceptual and procedural knowledge in solving mathematical problems in depth. The instrument used has been declared valid and reliable.

The triangulation carried out in this study is time triangulation. According to Miles and Huberman, data analysis is a data analysis technique: data reduction, data presentation, and concluding. 


\section{RESULTS AND DISCUSSION}

The results and discussion of this study are presented based on students' conceptual and procedural knowledge based on high, medium, and low categories in solving mathematical problems. The problem-solving steps presented in this study are problem-solving steps according to Polya, namely: understanding the problem, planning a solution, solving the problem, and checking again. Students' high conceptual and procedural knowledge in solving mathematical problems are described in the table below.

Table 1. High Students' Conceptual and Procedural Knowledge

\begin{tabular}{|c|c|c|c|c|}
\hline $\begin{array}{c}\text { Polya's } \\
\text { Problem } \\
\text { Solving Steps } \\
\end{array}$ & $\begin{array}{l}\text { Conceptual } \\
\text { Knowledge } \\
\text { Indicator }\end{array}$ & $\begin{array}{c}\text { Conceptual } \\
\text { Knowledge } \\
\text { High Students } \\
\end{array}$ & $\begin{array}{c}\text { Procedural } \\
\text { Knowledge } \\
\text { Indicator }\end{array}$ & $\begin{array}{c}\text { Procedural } \\
\text { Knowledge } \\
\text { High Students } \\
\end{array}$ \\
\hline $\begin{array}{l}\text { Understanding } \\
\text { the problem }\end{array}$ & $\begin{array}{l}\text { - Identify } \\
\text { relevant facts }\end{array}$ & $\begin{array}{l}\text { Students can identify } \\
\text { facts related to the } \\
\text { questions and find out } \\
\text { the information } \\
\text { contained in the } \\
\text { questions }\end{array}$ & $\begin{array}{l}\text { - Knowledge of } \\
\text { procedures in } \\
\text { general }\end{array}$ & $\begin{array}{l}\text { Students know some } \\
\text { general procedures that } \\
\text { will be used in } \\
\text { answering questions }\end{array}$ \\
\hline $\begin{array}{l}\text { Planning } \\
\text { solution }\end{array}$ & $\begin{array}{l}\text { - Recognize } \\
\text { examples and } \\
\text { non-examples } \\
\text { - Interpret signs, } \\
\text { symbols, and } \\
\text { terms } \\
\text { - Manipulating } \\
\text { related ideas }\end{array}$ & $\begin{array}{l}\text { Students know the } \\
\text { formula used to solve } \\
\text { some problems, } \\
\text { students can recognize } \\
\text { examples and not } \\
\text { examples, students can } \\
\text { manipulate related } \\
\text { ideas from several } \\
\text { questions }\end{array}$ & $\begin{array}{l}\text { - Knowledge of } \\
\text { procedures in } \\
\text { general }\end{array}$ & $\begin{array}{l}\text { Students can know and } \\
\text { apply algorithms or } \\
\text { procedures that have } \\
\text { been found to answer } \\
\text { some questions }\end{array}$ \\
\hline $\begin{array}{l}\text { Executing the } \\
\text { plan }\end{array}$ & $\begin{array}{l}\text { - Improving the } \\
\text { relationship } \\
\text { between } \\
\text { concepts and } \\
\text { principles }\end{array}$ & $\begin{array}{l}\text { Students get terms in } \\
\text { several questions and } \\
\text { then use or enter into } \\
\text { algebraic operations }\end{array}$ & $\begin{array}{l}\text { - Communicati } \\
\text { ng algorithmic } \\
\text { processes into } \\
\text { problem } \\
\text { situations }\end{array}$ & $\begin{array}{l}\text { Students can } \\
\text { communicate the } \\
\text { algorithm process into } \\
\text { situations in several } \\
\text { problems }\end{array}$ \\
\hline Verification & $\begin{array}{l}\text { - Improving the } \\
\text { relationship } \\
\text { between } \\
\text { concepts and } \\
\text { principles }\end{array}$ & $\begin{array}{l}\text { Students can perfect } \\
\text { the relationship of } \\
\text { concepts from initial } \\
\text { completion in several } \\
\text { problems }\end{array}$ & $\begin{array}{l}\text { - Modify } \\
\text { procedures } \\
\text { flexibly, } \\
\text { precisely, and } \\
\text { efficiently to } \\
\text { address } \\
\text { factors in } \\
\text { problem- } \\
\text { solving }\end{array}$ & $\begin{array}{l}\text { Students check the } \\
\text { process and the final } \\
\text { results they get for fear } \\
\text { of making mistakes in } \\
\text { answering them }\end{array}$ \\
\hline
\end{tabular}

\section{Understanding Problems}

Conceptual Knowledge:

High subjects who were then given the TS code were able to identify facts related to the questions, know the information contained in the questions, and understand the intent of the 3 test questions given by the researcher. The subjects knew the information contained in the questions. This can be seen from the results of student answers and the results of interviews conducted by researchers with TS subjects as follows:

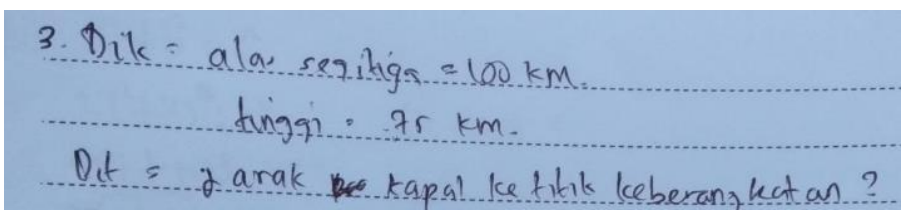

Figure 1. Understanding Problem 1 
When the interview was conducted, students understood that they could find information on the questions. Here's an excerpt from the interview:

PP.TS : In your opinion, how much information did you find from this question?

JS.TS : The first problem we find information about how to determine the length of the side of the base, the perpendicular and also the hypotenuse of a triangle.

In Figure 1, students can write down what is being asked and what is known about the questions. Students can identify the facts related to the questions. This can be seen from student answers on completing several other questions.

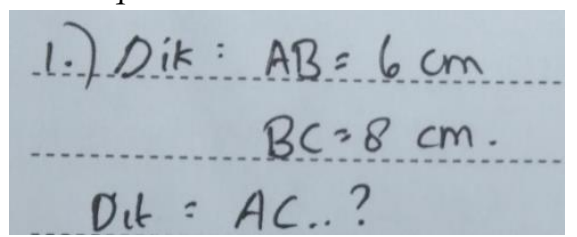

Figure 2. Understanding Problem 2

Procedural Knowledge:

TS subjects are able to know some general procedures that will be used in answering questions. This can be seen from the results of interviews conducted by researchers with TS subjects as follows: PP.TS : What steps are used to answer the question?

JS.TS : From the first problem we have to know the length of the hypotenuse and the base first. In the second problem, we have to know the perimeter of the rectangle first. In the third problem, we must first determine which side is the base and which side is upright.

The interview excerpt shows that the subject of TS can know the procedure used to solve the problem.

\section{Planning Solution}

Conceptual Knowledge:

TS subjects were able to know the formula used to solve several questions, this can be seen from the excerpts from interviews conducted by researchers with TS subjects as follows:

PP.TS : What concepts are used to answer the questions?

JS.TS : The Pythagorean theorem formula for questions number one, two and three.

PP.TS : What formula do you use to answer this question?

JS.TS : The Pythagorean theorem which contains $a^{2}+b^{2}=c^{2}$ for numbers one, two and three

Students can recognize examples and not examples. This can also be seen from the results of previous interviews. Students know the formula used to solve the problem by using the Pythagorean theorem, meaning that the student knows the example of the Pythagorean theorem. Students can manipulate related ideas from several questions. This can be seen from the results of student test answers as follows:

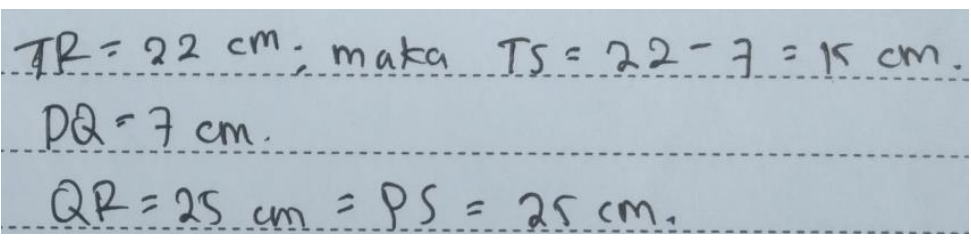

Figure 3. JS.TS Manipulating Related Ideas

In Figure 3, students can manipulate ideas related to the problem. It is stated in the question of 
the length of the sides TR, PQ, and QR to find the length of the QR. Students must understand the concepts in the picture, and students know that the side of the QR is parallel to the side of PS so that the lengths of both sides are the same.

Procedural Knowledge:

TS subjects can know and apply the algorithms or procedures that have been found to answer some questions. This can be seen from the results of the TS subject's answers as follows:

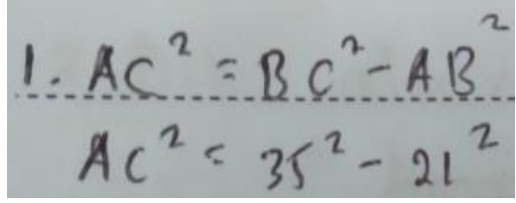

Figure 4. JS.TS Planning Solution 1

Subjects can manipulate formulas to be entered into algebraic operations according to what is asked of the question. If one side is asked or the other side, the algebraic operation used is subtraction. If the question is the hypotenuse length, the algebraic operation used is addition. This is in line with the results of students' answers in solving other questions.

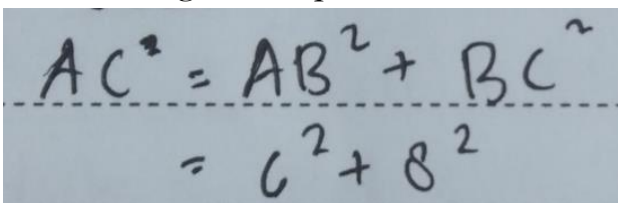

Figure 5. JS.TS Planning Solution 2

\section{Executing The Plan}

Conceptual Knowledge:

TS subjects get terms in several questions and then use or enter into algebraic operations. This can be seen in the image above, namely Figures 4 and 5 .

Procedural Knowledge:

TS subjects can communicate the algorithm process into situations in several problems. This is the next stage of problem planning. This can be seen from the results of the TS subject work as follows:

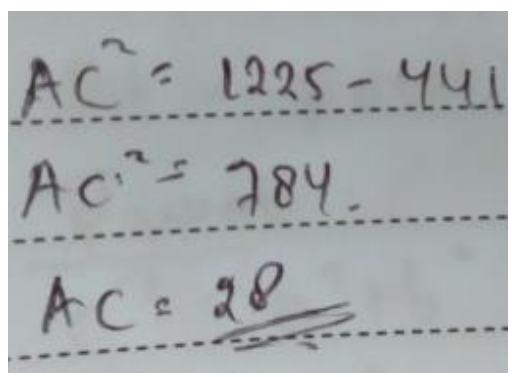

Figure 6. JS.TS Executing The Plan

In Figure 6, students can use problem-solving procedures correctly, and the calculations are also correct for all questions. Students calculate powers correctly, operate algebra correctly, and look for powers correctly to correct the final result. This is in line with the results of student work on other questions. 


\section{Verification}

\section{Conceptual Knowledge:}

The TS subject can perfect the concept relationship from the initial completion in several questions at this stage. This can be seen from the results of the work carried out by the TS subject in solving the following questions:

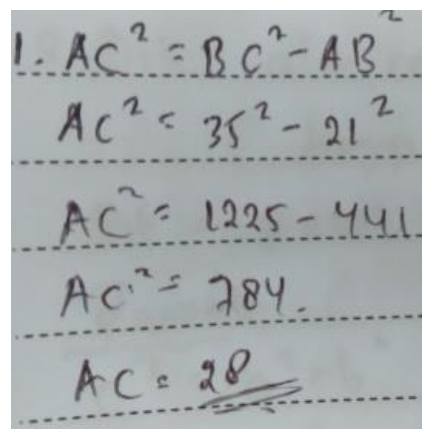

Figure 7. Verification

In Figure 5a, students can perfect the concept relationship from initial completion. Students can answer questions with the correct answer. Students understand the concept well and work on the problem correctly. This is also in line with the results of working on the TS subject on other questions.

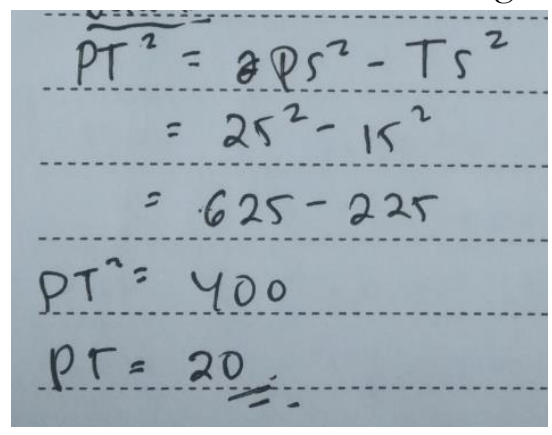

Figure 8. Verification

Procedural Knowledge:

TS subjects checked the process and the final results for fear of making mistakes in answering them. This can be seen from the results of interviews conducted by researchers with TS subjects as follows:

PP.TS : Did you check the final answer that was made?

JS.TS : Yes, I did.

PP.TS : How?

JS.TS : The trick is that I roll back the formulas because I already got the length of the hypotenuse, so I tried to find the upright side and what I got was also the same as the length of the up right side of the triangle in the problem and so on the side of the base.

The interview excerpt shows that the TS subject rechecked the results he had done, and the subject knew how to check the answers from the results he had obtained. Based on the resulting research, In the high group students in understanding the problem of conceptual knowledge, it was found that students were able to identify the facts related to the questions and know the information contained in the questions, from this it indicated that these students knew the information contained in the questions and were able to identify the facts related to the problem, from the question to what is asked in the question. This is supported by the results of research [14] that high-ability students can 
choose and organize appropriate information to solve problems. In procedural knowledge, students can find out some general procedures that will answer questions. Students have high procedural knowledge because students are accustomed to developing various ways to solve problems. It is also explained by [15] that students have high procedural knowledge when they know a clear procedural framework in accordance with the given problem situation.

In planning problems on conceptual knowledge, students know the formulas used to solve some problems. Students can recognize examples and not examples. Students can manipulate ideas related to several questions. When a student can plan a problem, it means that the student correctly understands the concepts used in solving the problem. This is also found in the results of previous research by [14] saying that high knowledge students can design actions before working on the problem. In procedural knowledge, students can know and apply algorithms or procedures that have been found to answer some questions. This is also said by [10] that students with high procedural knowledge can determine the steps needed to solve a problem.

Carrying out plans on conceptual knowledge, students get terms in several questions and then use them in algebraic operations. In procedural knowledge, students can communicate the algorithm process into situations in several problems, students can use problem-solving procedures correctly, and the calculations are also correct. This is also said from the research results that students who have high procedural knowledge can work on algorithms correctly.

The next step is to re-examine. On conceptual knowledge, students can perfect the concept relationship from initial completion in several questions. Procedural knowledge is obtained by students checking the process and the final results for fear of making mistakes in answering them. This is supported by research by [13], which states that subjects with high knowledge have better conceptual and procedural knowledge in solving mathematical problems than other subjects. Subjects cannot directly find what is known at the stage of understanding the problem. The subject needs to read repeatedly the problems given.

Descriptively, medium students' conceptual and procedural knowledge in solving mathematical problems are presented in the table below.

Table 2. Medium Students' Conceptual and Procedural Knowledge

\begin{tabular}{|c|c|c|c|c|}
\hline $\begin{array}{c}\text { Polya's } \\
\text { Problem } \\
\text { Solving Steps }\end{array}$ & $\begin{array}{l}\text { Conceptual } \\
\text { Knowledge } \\
\text { Indicator }\end{array}$ & $\begin{array}{c}\text { Conceptual } \\
\text { Knowledge } \\
\text { Medium Students }\end{array}$ & $\begin{array}{l}\text { Procedural } \\
\text { Knowledge } \\
\text { Indicator }\end{array}$ & $\begin{array}{c}\text { Procedural } \\
\text { Knowledge } \\
\text { Medium Students }\end{array}$ \\
\hline $\begin{array}{l}\text { Understanding } \\
\text { the problem }\end{array}$ & $\begin{array}{l}\text { - Identify } \\
\text { relevant facts }\end{array}$ & $\begin{array}{l}\text { Students can identify } \\
\text { related facts only from } \\
\text { a few questions and try } \\
\text { to find out the } \\
\text { information contained } \\
\text { in several questions }\end{array}$ & $\begin{array}{l}\text { - Knowledge of } \\
\text { procedures in } \\
\text { general }\end{array}$ & $\begin{array}{l}\text { Students know some } \\
\text { general procedures that } \\
\text { will be used in } \\
\text { answering some } \\
\text { questions }\end{array}$ \\
\hline $\begin{array}{l}\text { Planning a } \\
\text { solution }\end{array}$ & $\begin{array}{l}\text { - Recognize } \\
\text { examples and } \\
\text { non-examples } \\
\text { - Interpret signs, } \\
\text { symbols, and } \\
\text { terms } \\
\text { - Manipulating } \\
\text { related ideas }\end{array}$ & $\begin{array}{l}\text { Students have not } \\
\text { been able to know the } \\
\text { formula used to solve } \\
\text { some problems. } \\
\text { Students have not } \\
\text { been able to recognize } \\
\text { examples and not } \\
\text { examples. Students } \\
\text { cannot manipulate } \\
\text { ideas related to some } \\
\text { questions }\end{array}$ & $\begin{array}{l}\text { - Knowledge of } \\
\text { procedures in } \\
\text { general }\end{array}$ & $\begin{array}{l}\text { Students have not been } \\
\text { able to know and apply } \\
\text { the algorithms or } \\
\text { procedures that have } \\
\text { been found to answer } \\
\text { some questions }\end{array}$ \\
\hline $\begin{array}{l}\text { Executing the } \\
\text { plan }\end{array}$ & $\begin{array}{l}\text { - Improving the } \\
\text { relationship } \\
\text { between }\end{array}$ & $\begin{array}{l}\text { Students cannot } \\
\text { understand the terms } \\
\text { in some questions }\end{array}$ & $\begin{array}{l}\text { - Communicati } \\
\text { ng algorithmic } \\
\text { processes into }\end{array}$ & $\begin{array}{l}\text { Students have not been } \\
\text { able to communicate } \\
\text { the algorithm process }\end{array}$ \\
\hline
\end{tabular}




\begin{tabular}{|c|c|c|c|c|}
\hline $\begin{array}{c}\text { Polya's } \\
\text { Problem } \\
\text { Solving Steps }\end{array}$ & $\begin{array}{l}\text { Conceptual } \\
\text { Knowledge } \\
\text { Indicator }\end{array}$ & $\begin{array}{c}\text { Conceptual } \\
\text { Knowledge } \\
\text { Medium Students }\end{array}$ & $\begin{array}{l}\text { Procedural } \\
\text { Knowledge } \\
\text { Indicator }\end{array}$ & $\begin{array}{c}\text { Procedural } \\
\text { Knowledge } \\
\text { Medium Students }\end{array}$ \\
\hline Verification & $\begin{array}{l}\text { concepts and } \\
\text { principles } \\
\text { - Improving the } \\
\text { relationship } \\
\text { between } \\
\text { concepts and } \\
\text { principles }\end{array}$ & $\begin{array}{l}\text { Students have not } \\
\text { been able to perfect } \\
\text { the concept } \\
\text { relationship from the } \\
\text { initial completion in } \\
\text { several questions }\end{array}$ & $\begin{array}{l}\text { problem } \\
\text { situations } \\
\text { - Modify } \\
\text { procedures } \\
\text { flexibly, } \\
\text { precisely, and } \\
\text { efficiently to } \\
\text { address } \\
\text { factors in } \\
\text { problem- } \\
\text { solving }\end{array}$ & $\begin{array}{l}\text { correctly into several } \\
\text { problem situations } \\
\text { Students check the } \\
\text { process and the final } \\
\text { results they get }\end{array}$ \\
\hline
\end{tabular}

In the middle group, students in understanding the problem, conceptual knowledge was obtained by students being able to identify related facts only from a few questions and trying to find out the information contained in several questions. In procedural knowledge, students know some general procedures that will be used in answering some questions. When students understand the problem, they must read it repeatedly to get what information is contained in the question and to find out what kind of procedure will be used. As [16] said, the student must read more, so it takes a long time to understand the problem, and students do the reading repeatedly to understand the problem.

The next step is to plan the problem, conceptual knowledge: students have not been able to know the formula used to solve some questions, students have not been able to recognize examples and not examples, students cannot manipulate ideas related to some questions this happens because students lack practice in solving problems on similar matters and not understanding correctly the concepts that will be used to solve these problems is in line with the results of research conducted by [16] that students do not understand the concepts and lack of practice questions. Procedural knowledge: students have not been able to know and apply the algorithms or procedures that have been found to answer some questions.

Students do not understand the problem, so they make mistakes in planning problem solving, which affects the next step of problem-solving, namely implementing the plan and checking again. Without knowledge and understanding of the problems given, students can't solve the problem correctly.

In question number two, students cannot know the correct formula to solve the problem so that at the next stage, students do not get the correct answer. In question number three, students know the formula used to solve the problem. Still, students cannot manipulate the ideas related to the problem so that the procedure they do in solving the problem is wrong.

Descriptively, low students' conceptual and procedural knowledge in solving mathematical problems are presented in the table below.

Table 3. Low Students' Conceptual and Procedural Knowledge

\begin{tabular}{lllll}
\hline $\begin{array}{c}\text { Polya's } \\
\text { Problem } \\
\text { Solving Steps }\end{array}$ & $\begin{array}{c}\text { Conceptual } \\
\text { Knowledge } \\
\text { Indicator }\end{array}$ & $\begin{array}{c}\text { Conceptual } \\
\text { Knowledge } \\
\text { Low Students }\end{array}$ & $\begin{array}{c}\text { Procedural } \\
\text { Knowledge } \\
\text { Indicator }\end{array}$ & $\begin{array}{c}\text { Procedural } \\
\text { Knowledge } \\
\text { Low Students }\end{array}$ \\
\hline $\begin{array}{l}\text { Understanding } \\
\text { the problem }\end{array}$ & $\begin{array}{c}\text { - Identify } \\
\text { relevant facts }\end{array}$ & $\begin{array}{l}\text { Students can identify } \\
\text { facts related to the } \\
\text { questions and find out } \\
\text { the information } \\
\text { contained in the } \\
\text { questions }\end{array}$ & $\begin{array}{l}\text { Knowledge of } \\
\text { procedures in } \\
\text { general }\end{array}$ & $\begin{array}{l}\text { Students do not know } \\
\text { some general } \\
\text { procedures that will be } \\
\text { used in answering } \\
\end{array}$ \\
& & & questions \\
& & & \\
\end{tabular}




\begin{tabular}{|c|c|c|c|c|}
\hline $\begin{array}{c}\text { Polya's } \\
\text { Problem } \\
\text { Solving Steps }\end{array}$ & $\begin{array}{l}\text { Conceptual } \\
\text { Knowledge } \\
\text { Indicator }\end{array}$ & $\begin{array}{c}\text { Conceptual } \\
\text { Knowledge } \\
\text { Low Students }\end{array}$ & $\begin{array}{l}\text { Procedural } \\
\text { Knowledge } \\
\text { Indicator }\end{array}$ & $\begin{array}{c}\text { Procedural } \\
\text { Knowledge } \\
\text { Low Students }\end{array}$ \\
\hline $\begin{array}{l}\text { Planning a } \\
\text { solution }\end{array}$ & $\begin{array}{l}\text { - Recognize } \\
\text { examples and } \\
\text { non-examples } \\
\text { - Interpret signs, } \\
\text { symbols, and } \\
\text { terms } \\
\text { - Manipulating } \\
\text { related ideas }\end{array}$ & $\begin{array}{l}\text { Students only know } \\
\text { some of the formulas } \\
\text { used to solve some } \\
\text { problems. Students } \\
\text { have not been able to } \\
\text { recognize examples } \\
\text { and not examples. } \\
\text { Students cannot } \\
\text { manipulate ideas } \\
\text { related to some } \\
\text { questions. }\end{array}$ & $\begin{array}{l}\text { Knowledge of } \\
\text { procedures in } \\
\text { general }\end{array}$ & $\begin{array}{l}\text { Students are not able to } \\
\text { know and apply } \\
\text { algorithms or } \\
\text { procedures to answer } \\
\text { some questions }\end{array}$ \\
\hline $\begin{array}{l}\text { Executing the } \\
\text { plan }\end{array}$ & $\begin{array}{l}\text { - Improving the } \\
\text { relationship } \\
\text { between } \\
\text { concepts and } \\
\text { principles }\end{array}$ & $\begin{array}{l}\text { Students have not } \\
\text { been able to get the } \\
\text { correct term in the } \\
\text { problem and then use } \\
\text { it or put it into } \\
\text { algebraic operations }\end{array}$ & $\begin{array}{l}\text { - Communicati } \\
\text { ng algorithmic } \\
\text { processes into } \\
\text { problem } \\
\text { situations }\end{array}$ & $\begin{array}{l}\text { Students can } \\
\text { communicate the } \\
\text { algorithmic process only } \\
\text { in a number of } \\
\text { situations in several } \\
\text { problems }\end{array}$ \\
\hline Verification & $\begin{array}{l}\text { - Improving the } \\
\text { relationship } \\
\text { between } \\
\text { concepts and } \\
\text { principles }\end{array}$ & $\begin{array}{l}\text { Students are not able } \\
\text { to perfect the concept } \\
\text { relationship from the } \\
\text { initial solution in the } \\
\text { problem }\end{array}$ & $\begin{array}{l}\text { - Modify } \\
\text { procedures } \\
\text { flexibly, } \\
\text { precisely, and } \\
\text { efficiently to } \\
\text { address } \\
\text { factors in } \\
\text { problem- } \\
\text { solving }\end{array}$ & $\begin{array}{l}\text { Students do not recheck } \\
\text { their answers }\end{array}$ \\
\hline
\end{tabular}

In the low group of students in understanding the problem, the conceptual knowledge obtained can identify facts related to the problem and find out the information contained in the problem. Procedural knowledge was found that students did not know some general procedures to answer questions because they did not understand what concepts would be used to answer questions. Students did not know what procedures they would use to answer questions. This is supported by the results of [15] research which says that "when students have gained conceptual knowledge and understanding in the field of mathematics, they can see the relationship between concepts and procedures in solving problems" this is inversely proportional to what researchers get in analyzing the results student test.

In the next step of planning the problem, students only know some of the formulas used to solve some questions, students have not been able to recognize examples and not examples, students cannot manipulate ideas related to some of these questions because students have never practiced working on questions, so it is difficult to solve problems. Determine the formula and are unable to use the formula according to the existing problem and cannot manipulate the ideas related to the problem. This is in line with the results of research from [10]. Subjects with low group knowledge still have difficulty in making mathematical models.

\section{CONCLUSIONS AND SUGGESTIONS}

Conceptual knowledge and procedural knowledge of students with high abilities can identify facts related to questions, know formulas and manipulate formulas that will be used to solve problems, and know examples and not examples. The student can also know the procedure that will be used to solve the problem and check the final results he gets. Conceptual knowledge and procedural knowledge of students with moderate abilities cannot manipulate related ideas included in 
algebraic operations because students do not understand the concepts and procedures used to answer questions. In addition, students have not communicated the algorithm process correctly into several problem situations. Conceptual knowledge and procedural knowledge of students with low abilities cannot plan solutions, do not know the formula to be used, cannot manipulate related ideas that will be included in algebraic operations. In addition, students also do not know the procedure to be used.

\section{REFERENCE}

[1] Y. Ramalisa and W. Syafmen, "Analisis Pengetahuan Prosedural Siswa Tipe Kepribadian Sensing Dalam Menyelesaikan Soal Materi Sistem Persamaan Linear Dua Ariabel," EDUMATICA J. Pendidik. Mat., vol. 4, no. 1, pp. 30-36, 2014.

[2] B. Rittle-Johnson and M. Schneider, "Developing conceptual and procedural knowledge of mathematics," Oxford Handb. Numer. Cogn., vol. 1, pp. 1118-1134, 2014.

[3] D. K. H. Khashan, "Conceptual and Procedural Knowledge of Rational Numbers for Riyadh Elementary School Teachers," J. Educ. Hum. Dev., vol. 3, no. 4, pp. 181-197, 2014.

[4] D. M. Kadijevich, "Relating procedural and conceptual knowledge," Teach. Math., vol. 21, no. 1, pp. 15-28, 2018.

[5] J. R. Star and G. J. Stylianides, "Procedural and Conceptual Knowledge: Exploring the Gap Between Knowledge Type and Knowledge Quality," Can. J. Sci. Math. Technol. Educ., vol. 13, no. 2, pp. 169-181, Apr. 2013.

[6] J. Kilpatrick, "Understanding mathematical literacy: The contribution of research," Educ. Stud. Math., vol. 47, no. 1, pp. 101-116, 2001.

[7] N. FAIDA, "Profil Pemahaman Konseptual Dan Prosedural Peserta Didik Menurut Kilpatrick Berdasarkan Tingkat Kemampuan Matematika." 2018.

[8] G. Polya, "How to solve it: a new aspect of mathematical method second edition," The Mathematical Gazette, vol. 30. p. 181, 1978.

[9] E. Yudianto, "Profil Pengetahuan Konseptual dan Pengetahuan Prosedural Siswa dalam Mengidentifikasi Masalah Pecahan," AdMathEdu J. Ilm. Pendidik. Mat. Ilmu Mat. dan Mat. Terap., vol. 3, no. 1, 2016.

[10] L. Khamidah, "Pemahaman Konseptual dan Pengetahuan Prosedural Siswa Kelas VIII dalam Penyelesaian Soal Matematika pada Materi Sistem Persamaan Linier Dua Variabel," Pros. SI MaNis (Seminar Nas. Integr. Mat. dan Nilai Islam., vol. 1, no. 1, pp. 611-616, 2017.

[11] Wawan, A. Talib, and N. Djam'an, "Analisis Pemahaman Konseptual dan Prosedural Siswa dalam Menyelesaikan Soal Matematika Berdasarkan Gaya Belajar," Issues Math. Educ., vol. 1, no. 2, pp. 101-106, 2019.

[12] H. Liberna, "Hubungan Gaya Belajar Visual dan Kecemasan Diri Terhadap Pemahaman Konsep Matematika Siswa Kelas X SMK Negeri 41 Jakarta," JNPM (Jurnal Nas. Pendidik. Mat., vol. 2, no. 1, pp. 98-108, 2018.

[13] N. Sari, I. Indiati, and D. Endahwuri, "Analisis Kemampuan Berpikir Kritis Matematika Siswa ditinjau dari Pemahaman Konseptual dan Pengetahuan Prosedural," Imajiner J. Mat. dan Pendidik. Mat., vol. 2, no. 6, pp. 467-472, 2020.

[14] M. A. A. Saputri, "Pemahaman Konseptual Dan Prosedural Siswa Kelas XI DPIB 1 SMK Sore Tulungagung dalam Menyelesaikan Masalah Matematika Materi SPLDV Ditinjau dari Gaya Kognitif Tahun Ajaran 2019/2010,” UIN Satu Tulung Agung, Tulungagung, 2020.

[15] M. Mahmudah, "Pengetahuan Konseptual dan Prosedural Siswa dalam Menyelesaikan Soal Materi Program Linear Berdasarkan Kemampuan Akademik Siswa Kelas XI MAN 2 Tulungagung Tahun Ajaran 2017/2018,” UIN Satu Tulung Agung, 2018.

[16] R. Armanza and B. Asyhar, "Pemahaman Konseptual dan Prosedural Siswa SMA/MA dalam Menyelesaikan Soal Program Linier Berdasarkan Tipe Kepribadian," J. Tadris Mat., vol. 3, no. 2, pp. 163-176, Dec. 2020. 
Journal of Research on Mathematical Instruction, Vol. 3, No. 1, December 2021, 14-24

jrmi.ejournal.unri.ac.id, Online ISSN: 2715-6869

\section{BIOGRAPHY}

\section{Dita Felia}

Dita Felia was student in Mathematics Education Program at The Faculty of Teacher Training and Education, Batanghari University, Jambi. 081340616704

\section{Eni Defitriani}

Eni Defitriani is lecturer in Mathematics Education Program at The Faculty of Teacher Training and Education, Batanghari University, Jambi. 085266564333 